\title{
Biochemical and Histochemical Studies on the Distribution of Histamine in the Digestive Tract of Man, Dog and Other Mammals*
}

\author{
W. Lorenz, A. Schater, St. Heitland, R. Calvoer, and E. Werle \\ Institut für Klinische Chemie und Klinische Biochemie and Pathologisches Institut \\ der Universität München
}

Received May 12, 1969

Summary. 1. The distribution of histamine was determined in tissues of the digestive tract of man, dog, pig, cow, and sheep, especially in the oral mucosa, stomach, gallbladder, and pancreas.

2. After treatment with compound $48 / 80$, histamine was released from the frenulum linguae, soft palate, tongue, and thyroid gland of dogs, but not from the vestibulum oris, hard palate, pharynx, oesophagus, stomach, and pancreas (experiments in the dog). The release of histamine from the tongue showed regional differences and was lowest in the root and highest in the tip.

3. A parallelism could be shown between the histamine content and the mast cell density in different parts of the tongue, stomach and in the soft palate of untreated dogs and dogs treated with $48 / 80$. The mast cells in the gastric mucosa could be characterized by their staining properties as "atypical" mast cells, whereas those in the musculature of the tongue were "typical" mast cells.

4. The histamine content of the single mast cell was similar in all tissues $(3.2 \mathrm{pg} /$ cell in the tongue, 3.3 in the stomach, 4.8 in the soft palate and 3.4 in the submaxillary gland). Only the mast cells in the fundic mucosa showed a significantly lower histamine content $(1.9 \mathrm{pg} / \mathrm{cell})$. The mast cells of the fundus and body of the stomach of the dog seemed to store histamine which was released by $48 / 80$.

5. A new classification of histamine stores is proposed: "unspecific mast cell stores" and "tissue specific stores".

Key-Words: Histamine - Alimentary Canal - Mammals - Mast Cells.

In the digestive tract of mammals, the histamine content of the tissues has been examined more frequently than of other organ systems (for a survey see LoRENZ and WERLE, 1969). But in some of them, like the pancreas, gallbladder, and oral mucosa, nothing or very little is known about its concentration and distribution.

In the dog, cellular localization of the amine had been studied intensely in many tissues of the alimentary canal (FELDBERG and HARRIs, 1953; ARvy and Quivy, 1955, 1955a; Mota et al., 1956; Lorenz el al., $1968 \mathrm{c}$; AURES et al., 1968). Nevertheless, the results obtained by bio-

* Supported by a grant from Deutsche Forschungsgemeinschaft.

6 Naunyn-Schmiedebergs Arch. Pharmak. Bd. 265 
chemical and histochemical methods are not sufficient to characterize various types of histamine stores, which may occur in one single tissue. Especially since ENmRBÄcK (1966a-d) had differentiated two kinds of mast cells by their biochemical and histochemical properties, which he had called "typical" and "atypical" mast cells, it seemed necessary to investigate the problem whether histamine is actually localized in two types of stores only: the "mast cell store" and the "nonmast cell store" (Brodit et al., 1966).

In this study the concentration and distribution of histamine were determined in many tissues of the digestive tract, especially in some parts of the oral mucosa, in the pancreas, gallbladder, and stomach. Furthermore, by the aid of biochemical and histochemical methods we tried to characterize the stores of histamine in different organs of the alimentary canal of the dog.

\section{Methods}

Materials. The human tissues were obtained from four men who died of accidents. The tissues of the animals were obtained from a local slaughter house or from our laboratory. Mongrel dogs weighing $8-12 \mathrm{~kg}$ were narcotized by $10-15 \mathrm{mg} / \mathrm{kg}$ Nembutal ${ }^{*}$ and bled. The organs were removed immediately after the death of the animals, frozen by $\mathrm{CO}_{2}$ snow and held at $-20^{\circ} \mathrm{C}$, until the assay of histamine was performed.

Reagents: o-phthaldialdehyde (recrystallized from ligroin B. P. $50-70^{\circ} \mathrm{C}$ ), histamine dihydrochloride (Fluka, Basle), n-butanol (for chromatography, Riedel de Haën, Seelze), n-heptane, perchloric acid (Uvasol ${ }^{\circledR}$, Merck, Darmstadt); toluidine blue 0 for microscopy, lead acetate and Entellan (Merck, Darmstadt). We thank very much the Imperial Chemistry Industries, Manchester, for the gift of compound $48 / 80$.

Determination of Histamine. Histamine was measured spectrofluorometrically according to the method of SHORE $e t$ al. (1959). Blanks were obtained by omission of the condensation step and by carrying $4 \mathrm{ml}$ of $0.4 \mathrm{~N} \mathrm{HClO}_{4}$ through the whole procedure. The recoveries of $0.5-20.0 \mu \mathrm{g}$ histamine hydrochloride added to the tissue homogenates were $70-80 \%$.

The specifity of the method was proved by comparing the fluorescence spectra of the tissue extracts (in $0,1 \mathrm{~N} \mathrm{HCl}$ ) with that of standard histamine, and by comparing the histamine values obtained by the method of SHore et al. (1959) with those obtained by the biological assay of histamine on the isolated guinea-pig ileum using the highly specific antihistaminic drug antazoline (LORENZ and WERLE, 1969 a) as an antagonist. The results of the two methods corresponded upto a difference of only $\pm 5 \%$, the fluorescence spectra of the extracts were identical with those of standard histamine. All histamine values are expressed as $\mu \mathrm{g}$ histamine dihydrochloride/g wet weight.

Treatment of the Dogs with Compound 48/80. Adult mongrel dogs (pairs of the same litter) were treated on three successive days with i.m. injections of increased doses of $48 / 80(2.5 \mathrm{mg} / \mathrm{kg}, 3.5 \mathrm{mg} / \mathrm{kg}$ and $4.0 \mathrm{mg} / \mathrm{kg}$ daily). Then the animals were sacrificed and the tissues removed, as described under materials.

Staining of the Mast Cells with Toluidine Blue and Estimation of the Mast Cell Density. Specimens of the tissue adjacent to the ones used for the determination of hist- 
amine were fixed for 24 hours with $4 \%$ basic lead acetate. Then they were embedded in paraffin; $10 \mu$ sections were stained for $30 \mathrm{~min}$ with a $0.5 \%$ toluidine blue solution at pH 4.0 and mounted in Entellan. For the characterization of the "typical" or, "atypical" mast cells, the same sections or those following immediately on the paraffin block ( $5 \mu$ thickness) were stained for $30-45$ sec or 10 min with $0.1 \%$ toluidine blue solution at $\mathrm{pH} \mathrm{0.3,0.5,1.5}$ and 4.0, according to the method of ENERBÄCK (1966 b). The gastric mucosa was cut vertically to its surface. In each section the number of mast cells was counted in 25 fields of nearly $1 \mathrm{~mm}^{2}$ each. $2-3$ sections in layers of different depth were examined in each specimen of tissue. Also, cells degranulated to a large extent by the treatment of $48 / 80$ were counted. The density of mast cells is expressed as the number of cells/25 fields (averages of $2-3$ sections).

\section{Results}

\section{Histamine Content of Different Tissues in the Alimentary Tract of Man, Dog and other Mammals}

In the digestive tract of the $d o g$, the highest histamine concentrations were found in the stomach, duodenum, and palatine tonsils, the lowest in the pancreas, thyroid gland, gallbladder, and mucosa of the hard palate and vestibulum oris (Table 1). In the oral mucosa the histamine

Table 1. Histamine comtent of different organs in the digestive tract of the dog

\begin{tabular}{|c|c|c|}
\hline \multirow[t]{2}{*}{ Organ } & \multicolumn{2}{|c|}{ Histamine content $(\mu \mathrm{g} / \mathrm{g})$} \\
\hline & $\begin{array}{l}\text { Mean value } \\
\pm s \bar{x}\end{array}$ & Extreme values \\
\hline \multicolumn{3}{|l|}{ Head } \\
\hline $\begin{array}{l}\text { Vestibulum oris } \\
\text { Frenulum linguae } \\
\text { Tongue } \\
\text { Hard palate } \\
\text { Soft palate } \\
\text { Palatine tonsil } \\
\text { Pharynx }\end{array}$ & $\begin{array}{r}6.2 \pm 1.8 \\
16.9 \pm 1.6 \\
14.9 \pm 3.8 \\
4.1 \pm 1.1 \\
26.5 \pm 6.5 \\
61.5 \pm 16.5 \\
22.7 \pm 14.8\end{array}$ & $\begin{array}{r}3.8-8.2 \\
14.6-18.1 \\
10.8-21.4 \\
3.2-5.9 \\
20.6-90.3 \\
7.6-42.4\end{array}$ \\
\hline \multicolumn{3}{|l|}{ Neck and thorax } \\
\hline $\begin{array}{l}\text { Oesophagus } \\
\text { 'Thyroid gland } \\
\text { Thymus } \\
\text { Lymph node }\end{array}$ & $\begin{array}{r}14.4 \pm 3.0 \\
6.4 \pm 3.1 \\
24.9 \pm 26.0 \\
14.5 \pm 12.0\end{array}$ & $\begin{array}{r}10.1-17.7 \\
3.2-9.9 \\
6.7-66.4 \\
6.2-34.7\end{array}$ \\
\hline \multicolumn{3}{|l|}{ Abdomen } \\
\hline $\begin{array}{l}\text { Stomach } \\
\text { Duodenum } \\
\text { Ileum } \\
\text { Pancreas } \\
\text { Gallbladder } \\
\text { Spleen }\end{array}$ & $\begin{array}{r}66.5 \pm 12.3 \\
72.3 \pm 9.7 \\
40.5 \pm 10.2 \\
\mathbf{5 . 4} \pm 0.7 \\
4.8 \pm 0.7 \\
13.8 \pm 6.7\end{array}$ & $\begin{array}{r}36.4-101.9 \\
62.1-77.7 \\
27.0-50.4 \\
3.9-\quad 6.1 \\
3.1-\quad 5.7 \\
6.2-24.3 \\
\end{array}$ \\
\hline
\end{tabular}

$N=5-9$ animals. The mucosa of the vestibulum oris was removed from the cheeks. 
content increased from oral to aboral. The highest histamine concentrations were found in the soft palate and pharynx (Table 1). Since we obtained the same results in man (Table 2), it seems possible that histamine plays a role in the genesis of the inflammatory or allergic oedema of this region (glottic oedema).

Table 2. Histamine content of different tissues of the human mouth and pharynx

\begin{tabular}{lll}
\hline \multirow{2}{*}{ Organ } & \multicolumn{2}{l}{ Histamine content $(\mu \mathrm{g} / \mathrm{g})$} \\
\cline { 2 - 3 } & Mean value $\pm s \bar{x}$ & Extreme values $^{\mathrm{a}}$ \\
\hline Tongue, tip & $7.6 \pm \mathbf{3 . 6}$ & $4.8-12.9$ \\
$\quad$ body & $5.9 \pm 0.9$ & $4.6-6.8$ \\
$\quad$ root & $7.4 \pm 1.0$ & $6.2-8.5$ \\
Mucosa in the region of & & \\
$\quad$ the isthmus faucium & $19.4 \pm 9.5$ & $13.3-30.4$ \\
Palatine tonsil & $15.4 \pm 2.7$ & $12.7-19.0$ \\
Pharynx & $16.5 \pm 2.1$ & $13.2-20.3$ \\
\hline
\end{tabular}

a $N=\mathbf{4}$ (number of human beings tested).

Table 3. Histamine content of the pancreas and the gallbladder of different mammals

\begin{tabular}{|c|c|c|c|}
\hline \multirow[t]{2}{*}{ Organ, species } & \multirow[t]{2}{*}{$N$} & \multicolumn{2}{|c|}{ Histamine content ( $\mu \mathrm{g} / \mathrm{g})$} \\
\hline & & Mean value $\pm s_{\bar{x}}$ & Extreme values \\
\hline Pancreas pig & 5 & $5.1 \pm 0.6$ & $4.6-5.4$ \\
\hline cow & 6 & $13.8+1.5$ & $11.7-15.8$ \\
\hline calf & 6 & $6.7 \pm 2.3$ & $3.8-10.0$ \\
\hline sheep & 5 & $22.6 \pm 6.2$ & $16.8-33.0$ \\
\hline rat & 6 & $8.4 \pm 6.5$ & $3.0-21.1$ \\
\hline Gallbladder pig & 4 & $81.6 \pm 37.0$ & $38.5-114.0$ \\
\hline cow & 4 & $30.3 \pm 10.0$ & $22.4-49.8$ \\
\hline sheep & 5 & $8.1 \doteqdot 4.9$ & $2.1-13.4$ \\
\hline
\end{tabular}

$N=$ number of animals tested.

The histamine concentration of the pancreas and gallbladder varied from one species to another (Table 3 ). The highest histamine content of the pancreas was found in that of sheep, the lowest in dogs and pigs. The very low density of mast cells in the pancreas of the dog (ARvy and Qurvy, 1955a) can explain this finding. A very high histamine concentration was discovered in the gallbladder of the pig. It could be possible that histamine plays a role in the etiology of biliary dyskinesia. 


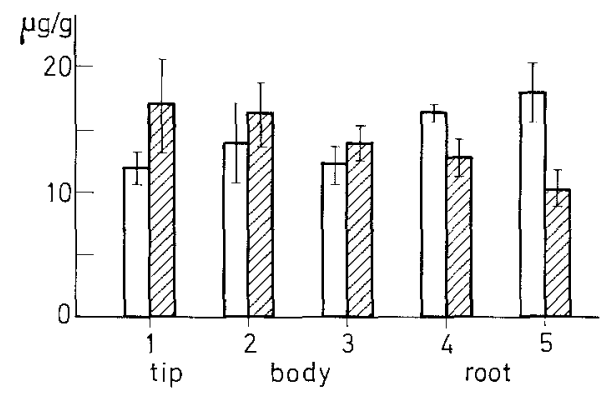

Fig. 1. Distribution of histamine in the tongue of the dog. Histamine in $\mu \mathrm{g} / \mathrm{g}, \bar{x} \pm \delta \bar{x}$, 5 animals tested. Strips of the mucosa and musculature were obtained by dissecting the tongue into 5 equal, $2-3 \mathrm{~cm}$ large pieces. Strip 1 corresponds to the tip, $2-4$ to the body and 5 to the root of the tongue. Differences of the histamine content in the mucosa: $4 / 1$ and $5 / 1 p<0.05$, in the musculature: $1 / 5$ and $2 / 5 p<0.05$.

$\square$ musculature

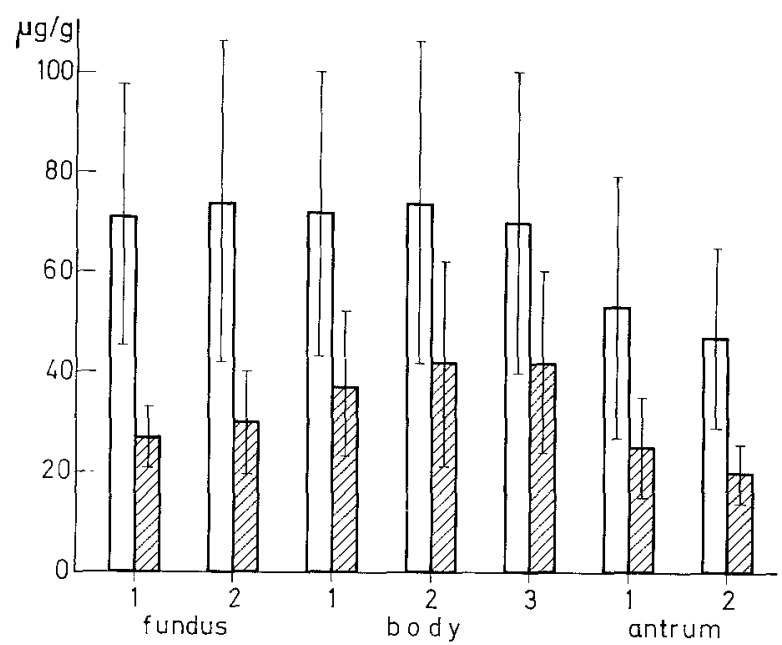

Fig. 2. Distribution of histamine in the stomach of the dog. Histamine in $\mu \mathrm{g} / \mathrm{g} . \bar{x} \pm s \bar{x}, 5$ animals tested. Strips of the mucosa and musculature were obtained by dissecting the stomach in 7 equal, $3-4 \mathrm{~cm}$ large pieces along the circular musculature. The mucosa was separated from the musculature (controlled by microscopy). Correlation between the histamine content of mucosa and musculature: $r=0,77 ; p<0.05$.

国 musculature; $\square$ mucosa

\section{Distribution of Histamine in the Tongue, Stomach and Pancreas}

Histamine is not uniformly distributed in tongue of dogs. In the mucosa the concentration increased from the tip to the root, in the muscular tissue from the root to the tip (Fig.1), corresponding to the change of the mast cell density (Table 8). 

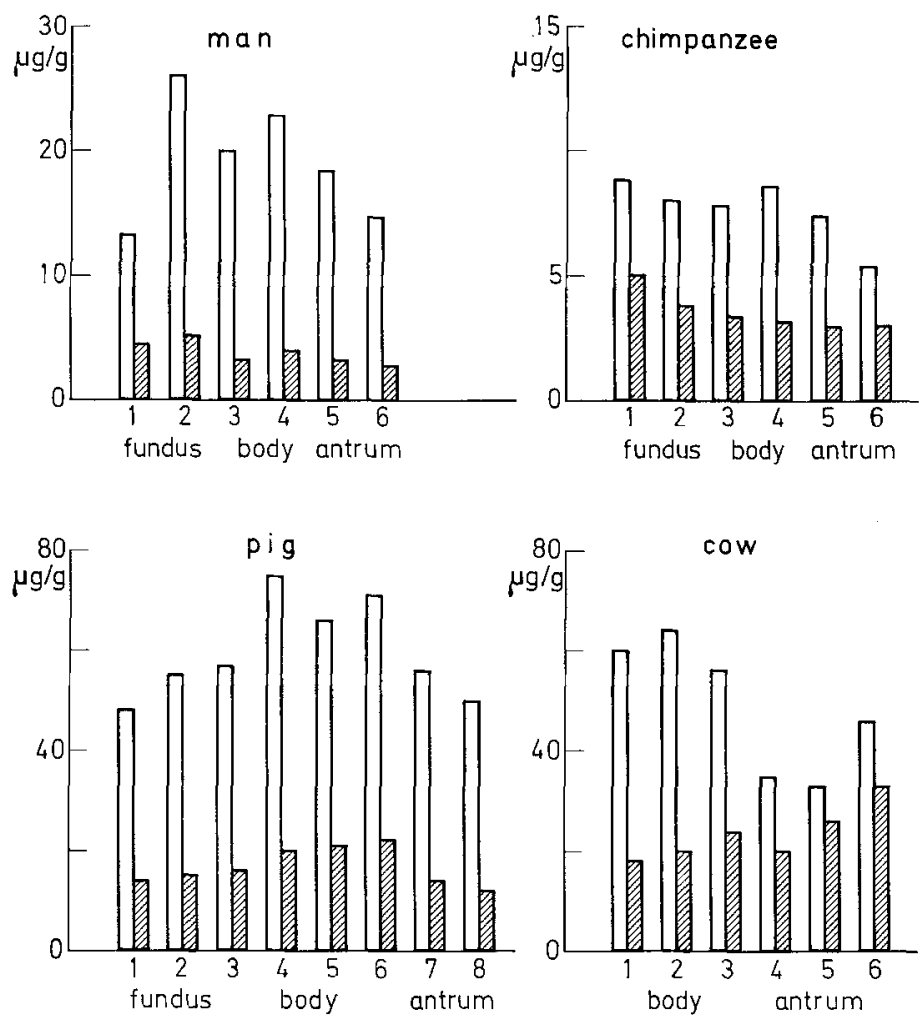

Fig. 3. Distribution of histamine in the stomach of man, chimpanzee, pig and cow. Histamine in $\mu \mathrm{g} / \mathrm{g}$, mean values $\pm s_{\bar{x}}, 2$ animals tested. Preparation of the mucosa and musculature according to Fig. 2 . Correlation between the histamine content of mucosa and musculature : $\operatorname{man}: r=0.97, p<0.001$; chimpanzee: $r=0.17$; cow: $r=0.35 ; \mathrm{pig}: r=0.91, p<0.001$. $\square$ mucosa, 0 musculature

In the gastric mucosa of the dog the highest histamine concentrations were found in the fundus and body, the lowest in the antrum (Fig. 2). Also in man, monkey, pig and cow (Fig. 3), the highest histamine content was measured in those regions of the gastric mucosa, showing the highest density of the acid forming parietal cells (ELLENBERGER and BAUM, 1912). Only in the rennet-bag of the cow, the histamine concentration strongly increased immediately at the pylorus, where parietal cells were very seldom (Lorenz and PfLEger, 1968d). The meaning of this interesting finding is not known, but it may be possible, that histamine in some species plays a role in the sphincter mechanism of the pylorus.

The muscularis propria and serosa of the dog's stomach showed only $48 \pm 8 \%$ of the histamine concentration of the mucosa, in the body 
$58 \%$ (Fig. 2). Whether this higher histamine content of the body muscularis has any influence on the blood flow in this region, is not known. But a parallelism could be demonstrated between the histamine content of the mucosa and that of the muscularis propria, not only in dogs (Fig.2), but also in men and pigs (Fig.3), whereas this correlation could not be shown in monkeys and cows. The histamine concentration of the muscularis propria was $18 \pm 1 \%$ of that of the mucosa in men, $28 \pm 3$ in pigs, $52 \pm 21$ in cows and $55 \pm 8$ in monkeys (Fig. 3). Therefore, the histamine content of the gastric muscularis propria was relatively high in monkeys, cows and dogs and low in men and pigs.

In the pancreas of dogs, cows and calves, histamine was uniformly distributed. If the two limbs of the dog's pancreas (canda and caput pancreatis) were divided in 3 equal parts, the following histamine concentrations were found as mean values of 6 animals (beginning at the end of the cauda $=$ left $\operatorname{limb}$ ): $4.1 \pm 1.1 ; 4.1 \pm 0.8$; $4.3 \pm 0.5 ; 4.4 \pm 1.2 ; 4.3 \pm 1.0 ; 4.8 \pm 1.4(\mu \mathrm{g} / \mathrm{g})$.

\section{Histamine Concentrations in Tissues of the Digestive Tract of Dogs after Treatment with 48180}

In the tongue of dogs, histamine was released by compound 48/80 to about $50-60 \%$ (Table 4 ). No significant difference existed between the mucosa and the musculature. However, similar to the histamine concentration, the histamine release by $48 / 80$ was not equal in all parts of the

Table 4. Histamine release in the tongue of the dog after treatment with compound 48/80

\begin{tabular}{|c|c|c|c|c|c|}
\hline \multirow[t]{2}{*}{ Tissue } & \multirow[t]{2}{*}{$N$} & \multicolumn{2}{|c|}{ Histamine content $(\mu \mathrm{g} / \mathrm{g})$} & \multirow[t]{2}{*}{ Release $(\%)$} & \multirow{2}{*}{$\begin{array}{l}\text { Significance } \\
(p)\end{array}$} \\
\hline & & Untreated & Treated & & \\
\hline Whole tongue & 9 & $14.9 \neq 3.8$ & $7.1+4.3$ & 52 & $<0.001$ \\
\hline Mucosa & 5 & $15.9 \pm 1.9$ & $7.0 \pm 0.3$ & 56 & $<0.001$ \\
\hline Musculature & 5 & $14.7 \pm 3.8$ & $5.8 \pm 0.3$ & 61 & $<0.001$ \\
\hline \multicolumn{6}{|l|}{ Mucosa } \\
\hline 1. strip & 9 & $14.9 \pm 5.0$ & $4.0 \pm 1.5$ & 73 & $<0.001$ \\
\hline 2. strip & 5 & $15.3 \pm 6.1$ & $5.2+2.4$ & 66 & $<0.001$ \\
\hline 3. strip & 9 & $14.1 \pm 3.9$ & $5.6 \stackrel{\perp}{\perp} 2.2$ & 60 & $<0.001$ \\
\hline 4. strip & 5 & $16.4 \pm 1.7$ & $10.1 \pm 0.9$ & 35 & $<0.025$ \\
\hline 5. strip & 9 & $18.6 \pm 5.0$ & $10.0 \pm 3.9$ & 46 & $<0.001$ \\
\hline \multicolumn{6}{|l|}{ Musculature } \\
\hline 1. strip & 9 & $18.4 \pm 6.7$ & $6.1 \pm 2.5$ & 67 & $<0.001$ \\
\hline 2. strip & 5 & $17.7 \pm 9.1$ & $6.6 \pm 2.4$ & 63 & $<0.001$ \\
\hline 3. strip & 9 & $14.5 \pm 3.2$ & $6.5 \pm 2.4$ & 55 & $<0.001$ \\
\hline 4. strip & 5 & $13.0 \pm 3.3$ & $6.3 \pm 2.0$ & 52 & $<0.001$ \\
\hline 5. strip & 9 & $9.4 \pm 3.0$ & $4.3 \pm 1.1$ & 64 & $<0.001$ \\
\hline
\end{tabular}

$\bar{x} \pm s \bar{x} . N=$ number of animals tested. Preparation of the tissue strips according to Fig. 1 . 
mucosa, whereas it showed only insignificant variations in the musculature (Table 4). Contrary to the histamine content, the histamine release by $48 / 80$ decreased in the mucosa from the tip to the root of the tongue $(73 \pm 14 \%$ in the first strip, $35 \pm 24 \%$ in the fourth strip, $p<0.02)$.

Table 5. Histamine release in the oral mucosa, pharynx and different organs of neck and thorax in the dog after treatment with compound $48 / 80$

\begin{tabular}{|c|c|c|c|c|}
\hline \multirow[t]{2}{*}{ Organ or tissue } & \multicolumn{2}{|c|}{ Histamine content $(\mu \mathrm{g} / \mathrm{g})$} & \multirow[t]{2}{*}{ Release $(\%)$} & \multirow[t]{2}{*}{ Significance $(p)$} \\
\hline & Untreated & Treated & & \\
\hline Vestibulum oris & $6.2 \pm 1.8$ & $7.8 \pm 5.7$ & 0 & - \\
\hline Frenulum linguae & $16.9 \pm 1.6$ & $11.0 \pm 4.7$ & 35 & $<0.05$ \\
\hline Hard palate & $4.1 \pm 1.1$ & $7.6 \pm 3.5$ & 0 & - \\
\hline Soft palate & $26.5 \pm 6.5$ & $17.0 \pm 5.5$ & 36 & $<0.02$ \\
\hline Pharynx & $22.7 \pm 14.8$ & $20.5 \pm 2.4$ & 10 & $>0.05$ \\
\hline Thyroid gland & $6.4 \pm 3.0$ & $2.7 \pm 1.4$ & 58 & $<0.025$ \\
\hline Thymus & $24.9 \pm 26.0$ & $13.7 \pm 6.5$ & 45 & $>0.05$ \\
\hline Lymph node & $14.5 \pm 12.0$ & $5.1 \pm 1.3$ & 65 & $>0.05$ \\
\hline Upper oesophagus & $12.5 \pm 3.8$ & $13.6 \pm 4.0$ & - & - \\
\hline Lower oesophagus & $16.3 \pm 2.2$ & $17.2 \pm 2.9$ & - & - \\
\hline
\end{tabular}

$\bar{x} \pm s \bar{x} .5$ pairs of animals were tested. The upper oesophagus reaches from the pharynx up to the division of the trachea, the lower part from the division of the trachea up to the cardia.

In the mucosa and the submucosa of the frenulum linguae and the soft palate, about $35 \%$ of histamine was released (Table 5), which was less than in the tongue. No histamine release could be shown in the mucosa and the submucosa of the vestibulum oris and the hard palate, which contained relatively much solid connective tissue, and in the walls of the pharynx (Table 5). In the regions of collum and thorax a significant histamine release could be demonstrated only in the thyroid gland (Table 5), which was similar to that of the tongue. No significant change of the histamine content could be observed in the thymus and lymph node, since the histamine values showed considerable variations in treated and untreated dogs.

Furthermore, no histamine release by $48 / 80$ could be shown in the upper and lower parts of the oesophagus and in different parts of the mucosa and musculature of the stomach (Table 6). On the contrary, the histamine concentration increased in the mucosa and musculature, but the difference between treated and untreated animals was of no statistical significance. Furthermore, no histamine release could be observed in the pancreas after i.m. injection of $48 / 80$ in dogs. 
Table 6

Histamine content of different parts of the dog's stomach after treatment with $48 / 80$

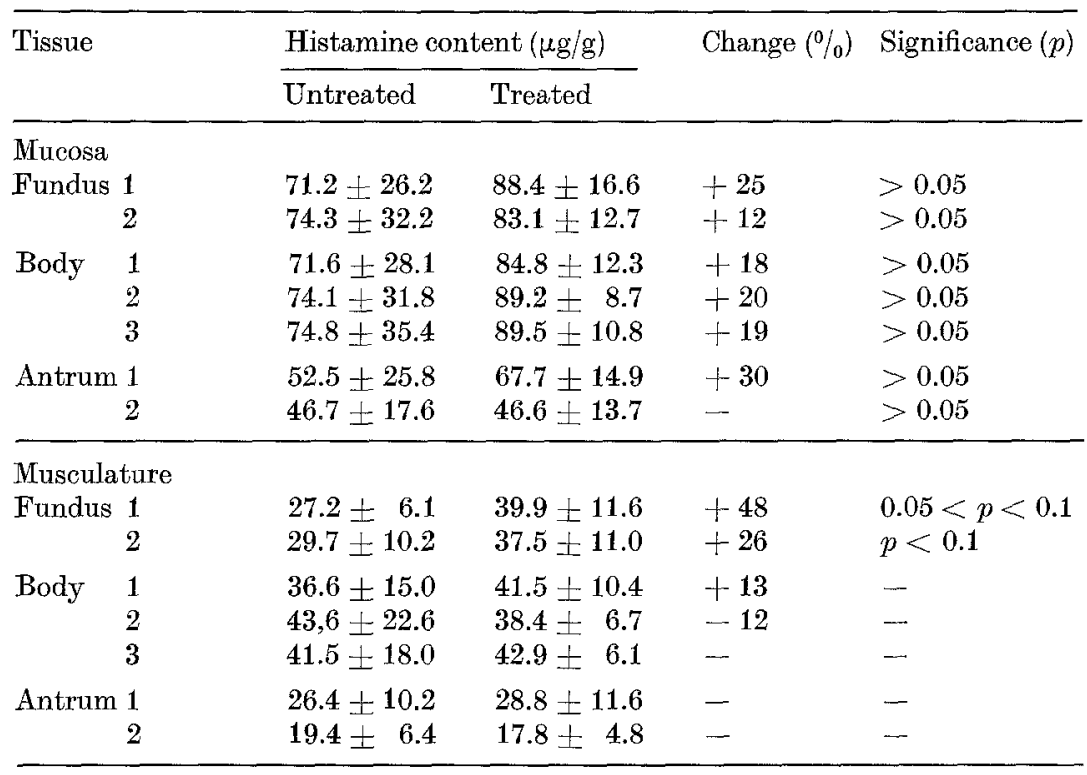

$\bar{x} \pm s \bar{x}$. Preparation of the stomach according to Fig. 2.5 pairs of animals tested.

\section{Correlation between the Histamine Content and the Mast Cell Density in Tissues of the Dog}

The highest mast cell density of all dog tissues was found in the gastric mucosa, the lowest in the submaxillary gland (Table 7). A highly significant correlation between the mast cell density and the histamine concentration of the tissues could be demonstrated (Fig.4). Since the regression line passed through the origin, nearly all histamine in these tissues seemed to be localized in mast cells. Only in the submaxillary gland, about $40 \%$ of the amine was non-mast cell histamine, as previously shown (Lorenz et al., 1968c). Therefore, the histamine value of the submaxillary gland in Fig. 4 was corrected for mast cell histamine.

After treatment with $48 / 80$, a parallel decrease of the histamine concentration and the mast cell density could be demonstrated in different parts of the mucosa and musculature of the tongue and in the soft palate (Table 8 ). The remaining histamine concentrations and mast cell densities in the tongue showed a correlation, the regression line of which passed through the origin (Fig.5a). These findings support the statement that nearly all histamine of those tissues was localized in mast cells. 


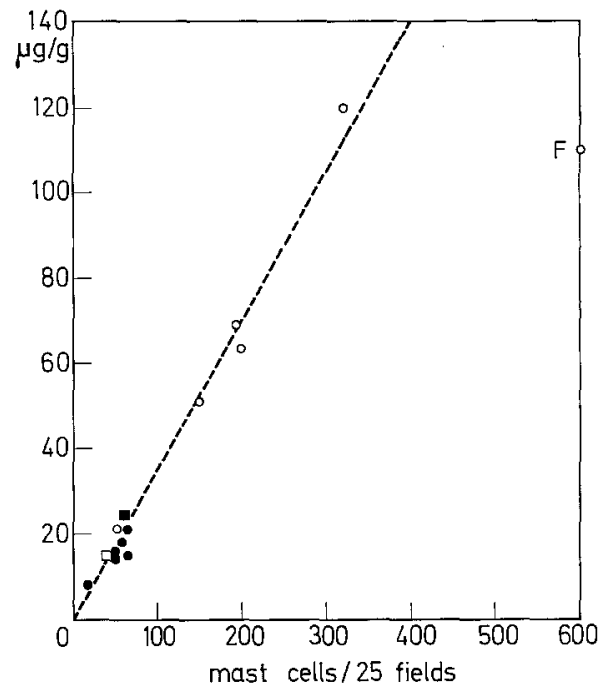

Fig.4. Correlation between the histamine content and the mast cell density of different organs in the digestive tract of dogs. Histamine content in $\mu \mathrm{g} / \mathrm{g}$, mast cell density in number of mast cells/25 fields. The strips 1, 3, 5 according to Fig. 1 were studied in the mucosa and musculature of the tongue, fundus 1 , body 2 and antrum 2 in the gastric mucosa and musculature according to Fig. 2. $F$ fundic mucosa. Each point in the graph corresponds to a mean value obtained from determinations in 5 animals. Coefficient of correlation $r=0.91, p<0.001$. $\bullet$ tongue, o stomach, soft palate, $\square$ submaxillary gland. The histamine value of the submaxillary gland was corrected for mast cell histamine (see text)

Table 7. Mast cell density in different organs or tissues of the dog

\begin{tabular}{lrcl}
\hline Organ or tissue & $N$ & \multicolumn{2}{c}{ Mast cell density } \\
\cline { 4 - 4 } & & Mean value $\pm s \bar{x}$ & Extreme values \\
\hline Tongue, mucosa & 15 & $60 \pm 20$ & $31-103$ \\
$\quad$ musculature & 15 & $44 \pm 26$ & $13-112$ \\
Soft palate & 5 & $51 \pm 13$ & $29-61$ \\
Submaxillary gland & 5 & $44 \pm 23$ & $17-68$ \\
Stomach, mucosa & 15 & $341 \pm 197$ & $55-705$ \\
\multicolumn{1}{c}{ musculature } & 15 & $131 \pm 89$ & $\mathbf{1 4 - 3 3 5}$ \\
\hline
\end{tabular}

Mast cell density given in number of cells/25 fields $\cong$ number of cells $/ \mathrm{mm}^{2}$. $N=$ number of tests. In the gastric mucosa and musculature one piece of tissue was removed from the fundus, body and antrum, in the tongue from strip 1,3 and 5 according to Fig. 1.

In the gastric mucosa and musculature of the fundus and body, we found a decrease of the mast cell density after treatment with 48/80, which was significant only in the mucosa of the fundus (Table 8), and 
92 W. Lorenz, A. Schauer, St. Heitland, R. Calvoer, and E. Werle:
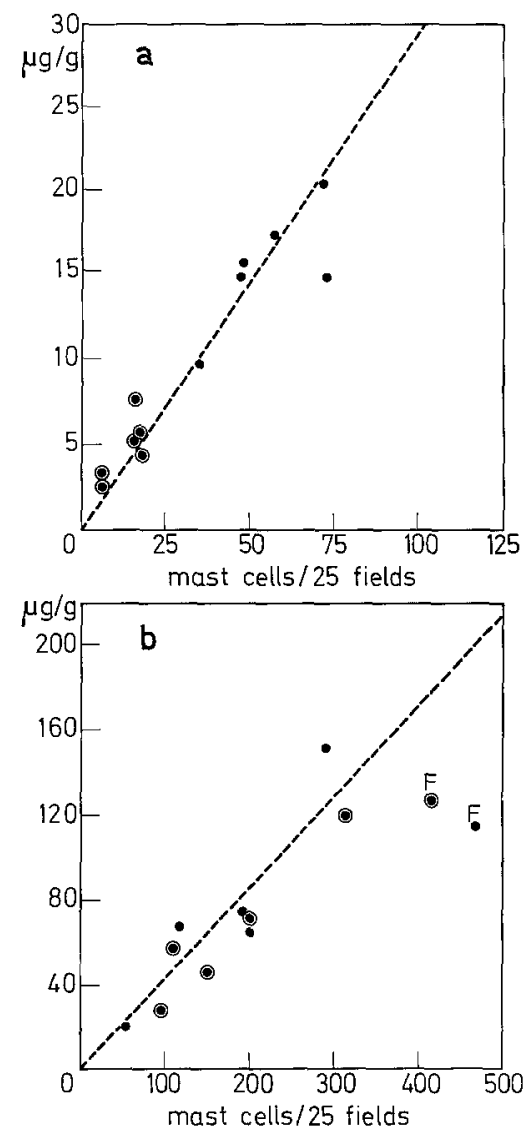

Fig. $5 \mathrm{a}$ and b. Correlation between the histamine content and the mast cell density of the tongue and the stomach in normal dogs and those treated with 48/80. Histamine content in $\mu \mathrm{g} / \mathrm{g}$, mast cell density in number of mast cells/25 fields. Each point in the graph corrseponds to a mean value obtained from determinations in 5 normal dogs $(\bullet)$ and those treated with $48 / 80(\odot)$. Pieces of tissue in the tongue and stomach according to Fig. 4 . $F$ fundic mucosa. a) tongue: $r=0.97, p<0.001$; b) stomach:

$$
r=0.86, p<0.001
$$

\section{Characterization of the Mast Cells in the Tongue and the Stomach by Staining with Toluidine blue at Different $p H$ Values}

The mast cells of the gastric mucosa, duodenum and ileum of the rat could be differentiated from those of other tissues (RILEY, 1959; Schauer, 1964): They were strongly resistant to $48 / 80$ and stained by $0.1 \%$ toluidine blue at $\mathrm{pH} 4.0$, but not at $\mathrm{pH} 0.3$. ENERBäck $(1966 \mathrm{a}-\mathrm{d})$ called these cells "atypical mast cells". 
a
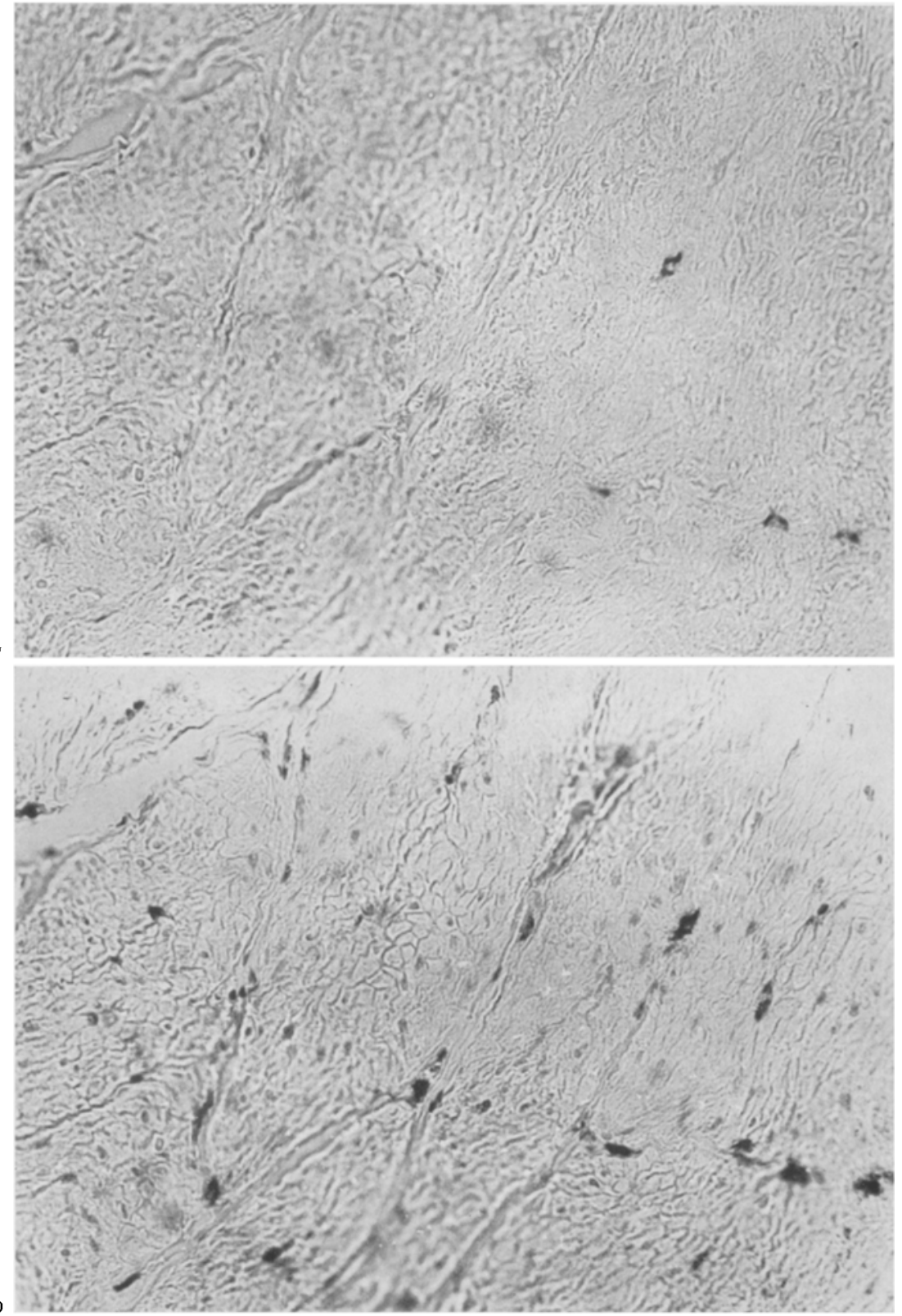

Fig. $6 \mathrm{a}$ and b. Staining of a section of the gastric musculature of the dog with toluidine blue $\left(0.1^{\circ}\right)$ at $p H 4.0$ and 0.3 . The same section was stained for 45 sec at $\mathrm{pH} 4.0$ and for 10 min at $\mathrm{pH} 0.3$ according to ENERBÄck $(1966 \mathrm{~b})$. It was obtained from body 2 according to Fig. $2 . \mathrm{a}=\mathrm{pH} 0.3, \mathrm{~b}=\mathrm{pH}$ 4.0. The mast cells appear as deeply black spots, note the great difference between the number of these cells at pH 0.3 and 4.0.

Magnification $300 \times$ 
Since the mast cells of some tissues of the dog were resistant to $48 / 80$, we examined the staining behaviour of these cells with $0.1 \%$ toluidine blue at $\mathrm{pH} 4.0 ; 1.5 ; 0.5$ and 0.3 . In all parts of the musculature of the tongue (according to Fig.1) no difference could be fond in the mast cell density at different $\mathrm{pH}$-values before and after treatment with $48 / 80$. In the mucosa, this was only the case in the tip and body of the tongue, but not in the root, where about $40 \%$ of the mast cells disappeared at $\mathrm{pH}$ 0.3. Therefore, the mast cells of the tongue seemed to be typical mast cells, with the exception of $40 \%$ in the mucosa of the radix linguae, which were atypical mast cells. In the gastric mucosa and musculature of fundus, body and antrum of untreated dogs, only $39 \%$ of the mast cells could be stained with $0.1 \%$ toluidine blue at pH 1,5 , and only $18 \%$ at $\mathrm{pH} 0.3$ (for example see Fig. $6 a, b$ ). In dogs treated with $48 / 80$, practically no mast cells could be shown in the gastric mucosa at $\mathrm{pH} 0.3$. Thus about $20 \%$ of the mast cells of the gastric mucosa seemed to be typical mast cells by their staining properties and their sensitivity towards $48 / 80$ (see above) and $80 \%$ seemed to be ,atypical" mast cells. Indeed, the mast cells of the gastric mucosa were much smaller than those in the musculature of the tongue. The increase of the histamine content and the mast cell density in the antrum mucosa after 48/80 was somewhat surprising, but ENERB̈̈CK (1966c) obtained the same results in the duodenum of rats after the treatment with $48 / 80$.

In the stomach of the rat, the typical mast cells had been found only in the submucosa, while all mucosal mast cells were "atypical" (AURES et al., 1968). In the dog's stomach too, the "typical" mast cells occurred only in the basal layers of the mucosa and in the submucosa. This could be shown by staining of the sections with $0.1 \%$ toluidine blue at $\mathrm{pH} 0.3$, and by a reduction of the mast cell density after treatment of the animal with 48/80 (Table 9). In the upper two thirds of the corpus mucosa the number of mast cells $/ \mathrm{mm}^{2}$ was the same as in the basal third and in the submucosa. Contrary to that, in the fundic mucosa it was in the upper layers about $25 \%$ higher than in the basal layers and in the submucosa. In dogs treated with $48 / 80$, this difference was statistically significant $(p<0.05)$.

\section{Histamine Content of the Single Mast Cell in Normal Dogs and Those Treated with $48 / 80$}

The histamine content of the single mast cell has been calculated from the histamine concentration per $\mathrm{g}$ tissue and the number of mast cells per $\mathrm{cm}^{3}$. It was $3.2 \pm 0.9 \mathrm{pg}(1.4-7.1)$ in the tongue, $3.3 \pm 0.7 \mathrm{pg}$ $(1.6-14.1)$ in the stomach, $4.8 \pm 1.4 \mathrm{pg}(2.0-8.4)$ in the soft palate and $3.4 \pm 0.9(1.5-6.7)$ in the submaxillary gland. 
Table. 9. Mast cell density in different layers of the gastric mucosa and the muscularis mucosae in the fundus and body of the dog after treatment with 48/80

\begin{tabular}{|c|c|c|c|}
\hline \multirow[t]{2}{*}{ Layer } & \multicolumn{2}{|c|}{$\begin{array}{l}\text { Mast cell density (number of cells/ } \\
25 \text { fields) }\end{array}$} & \multirow[t]{2}{*}{$\begin{array}{l}\text { Decrease } \\
(\%)\end{array}$} \\
\hline & Untreated & Treated & \\
\hline \multicolumn{4}{|l|}{ Fundic mucosa } \\
\hline Upper two thirds & $583 \pm 215$ & $575 \pm 74$ & - \\
\hline $\begin{array}{l}\text { Basal third and muscularis } \\
\text { mucosae }\end{array}$ & $474 \pm 66$ & $445 \pm 99$ & 6 \\
\hline \multicolumn{4}{|l|}{$B o d y$} \\
\hline Upper two thirds & $303 \pm 69$ & $299 \pm 152$ & - \\
\hline $\begin{array}{l}\text { Basal third and muscularis } \\
\text { mucosae }\end{array}$ & $316 \pm 124$ & $261 \pm 129$ & 18 \\
\hline
\end{tabular}

$\bar{x} \pm s \bar{x} .5$ pairs of animals tested, the fundic mucosa corresponded to fundus 1 , the body mucosa to body 2 in Fig. 2.

Table 10. Histamine content of the single mast cell in different tissues of the dog after treatment with $48 / 80$

\begin{tabular}{|c|c|c|c|c|c|}
\hline \multirow[t]{2}{*}{ Tissue } & \multirow[t]{2}{*}{$N$} & \multicolumn{2}{|c|}{ Histamine content ( $\mathrm{pg} / \mathrm{cell})$} & \multirow{2}{*}{$\begin{array}{l}\text { Increase } \\
(\% / 0)\end{array}$} & \multirow{2}{*}{$\begin{array}{l}\text { Significance } \\
(p)\end{array}$} \\
\hline & & Untreated & Treated & & \\
\hline \multicolumn{6}{|l|}{ Stomach } \\
\hline \multicolumn{6}{|l|}{ Mucosa } \\
\hline Fundus 1 & 9 & $1.9 \pm 0.8$ & $3.5 \pm 1.0$ & 85 & $<0.005$ \\
\hline Body 2 & 9 & $4.0 \pm 1.8$ & $6.2 \pm 2.0$ & 55 & $<0.05$ \\
\hline Antrum 2 & 9 & $3.8 \pm 2.2$ & $4.0 \pm 1.3$ & - & - \\
\hline \multicolumn{6}{|l|}{ Musculature } \\
\hline Fundus 1 & 5 & $4.5 \pm 2.7$ & $5.3 \pm 2.5$ & 18 & $<0.2$ \\
\hline Body 2 & 5 & $4.1 \pm 2.1$ & $5.4 \pm 0.9$ & 32 & $<0.1$ \\
\hline Antrum 2 & 5 & $4.2 \pm 2.3$ & $3.8 \pm 2.1$ & - & - \\
\hline \multicolumn{6}{|l|}{ Tongue } \\
\hline Mucosa (strip 3) & 5 & $2.5 \pm 0.8$ & $2.5 \pm 1.6$ & - & - \\
\hline Musculature (strip 3 & 5 & $3.6 \pm 2.3$ & $3.6 \pm 1.4$ & - & - \\
\hline
\end{tabular}

$\bar{x} \pm s \bar{x}$. Tissue pieces named according to Fig. 1 and 2. Calculation of the histamine content of the single mast cell from the histamine content/g and the number of mast cells $/ \mathrm{cm}^{3}=$ number of mast cells $/ 25$ fields $\times 100000$ (thickness of the section $0.01 \mathrm{~mm}$, area of $1 \mathrm{~mm}^{2}$ ).

The mean content of at all investigated was $3.7 \pm 0.8 \mathrm{pg}$. For comparison, the values found by other investigators are given: $1.14 \mathrm{pg}$ in the cat skin (RILEY, 1959), 10-15 pg in the mesentery of the rat (UVNäs 
and Thon, 1966), $1 \mathrm{pg}$ in the basophile granulocyte (VAN Arsdel and BraY, 1961), 6.7-15.6 pg in different tissues of the dog (GraHam et al., 1955), 18 and $24 \mathrm{pg}$ in the liver capsule of calves and oxes (RחEY, 1959 ), 25-34 pg in different tissues of the guinea-pig (BoRḱus and Chakravarty, 1960).

The histamine content of the single mast cell was nearly the same in all tissues studied in the dog. Only the mast cells of the fundic mucosa showed a histamine concentration which was about $50 \%$ lower than that of the body mucosa $(p<0.01)$ and that of the other tissues examined (Table 10, of. Fig.5b). Since the animals were starved 12 hours before death, an influence of feeding could not explain these findings. But after treatment of the dogs with $48 / 80$, the histamine content of the mast cells of the fundic mucosa increased to about $85 \%$, and was now similar to that of the other tissues. Also, the histamine concentration of the mast cells of the body mucosa increased to about $55 \%$ and reached values which were the highest of all mast cells in the dog as far as investigated (Table 10). Furthermore, a small, not significant increase in the histamine content of the single mast cell could be observed in the musculature of the fundus and body after application of 48/80 (Table 10). In the other tissues the histamine content of the mast cells remained unchanged. Since it is known, that the "atypical" mast cells can store monoamines (ENERBÄCK, $1966 \mathrm{~d}$ ), it seems probable that the increase of the histamine content of the single mast cell in the fundus and body is due to an uptake and storage of histamine released from typical mast cells in the whole body by $48 / 80$. An uptake of exogenous histamine by the gastric mucosa of dogs has been described (CODs, 1965). Contrary to the "atypical" mast cells, the typical mast cells cannot take up and store exogenous histamine (SCHAYER, 1956).

\section{Discussion}

The studies on a possible physiological rôle of histamine in the digestive tract were focussed on the stimulation of gastric secretion (CODE, 1966; Lorenz and PfLeger, 1968d). But histamine has probably some other physiological functions in the alimentary tract, too.

For instance, a mediator rôle of this amine was discussed in the detoxication mechanisms of the Waldeyer's tonsillar ring by the enhancement of the permeability for different toxins (GASTPAR and LORENZ, 1968). Specific histidine decarboxylase and diamine oxidase were demonstrated in the tonsils (GASTPAR and LORENZ, 1968). The induction of the histidine decarboxylase by the toxins could play a rôle in the focal infection, since the "induced" histamine (SCHAYER, 1966) would enhance the permeability not only in the direction from the blood into the lympoid tissue, but also from this tissue into the blood-stream (GASTPAR and LoRENZ, 1968).

Distribution and metabolism of histamine in the pancreas have been studied only in the rat (Emrnger et al., 1968; LoRENz et al., 1968a). A release of histamine 
into the pancreatic juice of dogs during secretion could be shown by LoRENz et al. (1968 b). But, contrary to the submaxillary and parotid glands (LORENz and PFLEGER, 1968d; LORENZ and WERLE, 1969a), the pancreatic secretion induced by histamine and secretin could not be inhibited by several antihistaminic drugs (LORENz et al., in preparation). Since even high doses of antihistiminics with a strong cholinolytic action (promethazine and piprinhydrinate) were ineffective after injection into the A. pancreaticoduodenalis, the conclusion was that these drugs could penetrate only in small amounts into the pancreatic tissue (Lorenz, 1969). Further studies are necessary to elucidate the function of histamine in this gland.

In all studies on the possible physiological function of histamine, the cellular localization of this amine plays an important rôle. Different methods of solving this problem should be combined, since no biochemieal or histochemical assay by its own is able to characterize the histamine stores qualitatively and quantitatively with a complete reliability. The fluorescence microscopical techniques seem to have two sources of error: These methods suffer from a limited sensitivity, and tissue components, like guanidines and thioimidazoles, could inhibit the formation of the complex between o-phthalaldehyde and histamine (Lorman et al., 1968e). The following procedures were chiefly ased: Determination of the correlation between the histamine content and the mast cell density (RILEY and WEST, 1953); estimation of the histamine release by typical liberators, like $48 / 80$ (mast cell histamine) or reserpine (non-mast cell histamine) (Maclstosh and PATON, 1949; BrodIt et al., 1966); histochemical (SOHAUER and WERLE, 1959) and fluorescence microscopical demonstration of histamine (JUHLTN and SHeLLEx, 1966; THUNBERG, 1967; HAkANson et al., 1967, $1967 \mathrm{a}, \mathrm{b}$ ); histochemical characterization of the mast cell type (ENERBÄCK, $1966 \mathrm{a}$ to d). Other methods, which are not so often used, should be mentioned: Autoradiography after application of ${ }^{14} \mathrm{C}$-histamine (WeINsheLBAOM and FezGUSON, 1966), the fractionating of cells of the blood (Code, 1937; MINARD, 1940), and of cell particles of the tissues (Mota et al., 1954; SNynder et al., 1966; KataOKa and DE RoBERTIS, 1967).

Since the cellular localization of histamine in the gastric mucosa and the musculature of the tongue has been studied with the aid of the four methods chiefiy used (Feldberg and TALESNIK, 1953; LoRENZ and PfLegrr, 1968d; Aures et al., 1968; and this paper) complete evidence is presented, that histamine in gastric mucosa (fundus and body) is localized to about $80 \%$ in "atypical" and to about $20 \%$ in "typical" mast cells and in the musculature of the tongue to about $100 \%$ in typical mast cells. In all of the other tissues of the dog further studies seem to be necessary, especially by the fluorescence microscopy.

Bropre et al. (1966) differentiated two types of histamine stores, mast cell and non-mast cell store. Histamine can be released from the mast cell store by the compound $48 / 80$ and from the non-mast cell store by reserpine and by parasympathetic stimuli. Since the "atypical" mast cells with properties of the non-mast cell stores (ENERBÄck, 1966d) have been discovered, this classification seems to be questionable. According to the morphology and the functional significance we would prefer the terms "unspecific mast cell" stores and "tissue specific" stores. The former are found in all tissues, the latter only in one or few tissues. The former are localized only in mast cells, the latter in "atypical" mast cells, entero- 
chromaffin and enterochromaffinlike cells (HÅkANsoN etal., 1967, 1967a,b), nerve endings (SNYDER et al., 1966; KATAOKA and De RoBERTIS, 1967) or in a new cell system in the pancreas and hypophysis (EHINGER et al., 1968). The former may have a similar function in all tissues, like regulation of the blood flow, the latter seem to have a specific function, like stimulation of the gastric or salivary secretion (LorEnz et al., 1968 b).

\section{References}

ARSDEL, P.P. VAN, JR., and R.E.BRAY: On the release of histamine from rat peritoneal mast cells by compound 48/80: Effects of metabolic inhibitors. J. Pharmacol. exp. Ther. 133, 319 (1961).

ARvy, L., et D. QuIvy : Relation entre la richesse en labrocytes et la teneur en histamine des divers segments du tube digestif ehez le chien. C. R. Soc. Biol. (Paris) 149, 658 (1955).

- Dormées sur la répartition des labrocytes chez le chien. C. R. Ass. Anat. $42,234(1955$ a).

Adres, D., R. HÅkanson, Ch. Owman, and B. Sporrong: Cellular stores of histamine and monamines in the dog stomach. Life Sci. 7, 1147 (1968).

Boréus, L. O., and N. Chakravarty: The histamine content of guinea-pig mast cells. Experientia (Basel) 16, $192(1960)$.

Brodie, B. B., M. A. Beaven, F. ErJevio, and H. L. Johnson: Uptake and release of $\mathrm{H}^{3}$-histamine. In: Mechanisms of release of biogenic amines, Wenner-Gren Center International Symposium Series, Vol. 5, p. 401. Oxford: Pergamon Press 1966.

CoDk, C.F.: The source in blood of the histamine like contituent. J. Physiol. (Lond.) 90, 349 (1937).

- Histamine and gastric secretion a later look 1955-1965. Fed. Proc. 25, 1311 (1965).

Eminger, B., R. Hikanson, Ch. Owman, and B. Sporrong: Histochemical demonstration of histamine in paraffin sections by a fluorescence method. Biochem. Pharmacol. 17, 1997 (1968).

Ellenberger, W., u. H. Baum: Handbuch der vergleichenden Anatomie der Haustiere, S. 419. Berlin: A. Hirschwald 1912.

ENERBÄOK, L.: Mast cells in rat gastrointestinal mucosa. 1. Effects of fixation. Acta path. microbiol. scand. 66, 289 (1966a).

- Mast cells in rat gastrointestinal mucosa. 2. Dye-binding and metachromatic properties. Acta path. microbiol. scand. 66, 303 (1966 b).

- Mast cells in rat gastrointestinal mucosa. 3. Reactivity towards compound 48/80. Acta path. microbiol. scand. 66, 313 (1966c).

- Mast cells in rat gastrointestinal mucosa. 4. Monoamine storing capacity. Acta path. microbiol. scand. 67, $365(1966 \mathrm{~d})$.

FELDBERG, W., and G.W.HARRIS: Distribution of histamine in the mucosa of the gastro-intestinal tract of the dog. J. Physiol. (Lond.) 120, 352 (1953).

-, and J.Taldesnik: Reduction of tissue histamine by compound 48/80. J. Physiol. (Lond.) 120, 550 (1953).

GastPaR, H., u. W. LoRmin: Speicherung, Bildung und Umsatz von Histamin in Speicheldrüsen und Tonsillen. Arch. klin. exp. Ohr.-, Nas.- u. Kehlk. Heilk. 191, 715 (1968).

Gratam, H.T., D.H. Lowry, N. WaHL, and M.K. Priebat: Mast cells as sources of tissue histamine. J. exp. Med. 102, 307 (1955). 
Hákanson, R., B.Litua, and Ch. Owman: Properties of a new system of aminestoring cells in the gastric mucosa of the rat. Europ. J. Pharmacol. 1, 188 (1967a).

- - - and S.THUNELL: Changes in gastric secretion induced by certain amines, amine precursors and related enzyme inhibitors. Europ. J. Pharmacol. 1, 425 (1967b).

- Ch. Owman, and N. O. Suöberg: Cellular stores of gastric histamine in the developing rat. Life Sci. 6, 2535 (1967).

JUHLIN, L., and W. B. SHELLEY: Detection of histamine by a new fluorescent ophthalaldehyde stain. J. Histochem. Cytochem. 14, 525 (1966).

KATAOKA, K., and E.DE ROBERTIS: Histamine in isolated small nerve endings and synaptic vesicles of rat brain cortex. J. Pharmacol. exp. Ther. 156, 114 (1967).

LoRkNz, W.: Lokalisation, Stoffwechsel und Frage einer physiologischen Funktion von Histamin in Speicheldrüsen, Schilddrüse und Magen. Habilitationsschrift, München 1969.

- M. Gerant, and E. WhrLe: Induction of the specific histidine decarboxylase by TSH and 2-mercaptobenzimidazole-1,3-dimethylol (MBI). Naunyn-Schmiedebergs Arch. Pharmak. exp. Path. 260, 171 (1968a).

- St. Halbach, M. Gerant, and E. Werle: Specific histidine decarboxylases in the gastric mucosa of man and other mammals: Determination, location and properties. Biochem. Pharmacol. (in press) (1969).

- G. HaUbensak, M. HUTzer u. E. WerLe: Histaminliberierung in Gl. submaxillaris und Pankreas durch Parasympathicomimetica, Peptidhormone, Histamin und Mepyramin. Naunyn-Schmiedebergs Arch. Pharmak. exp. Path. 260, 416 (1968b).

- St. Heitland, A. Schader, H. Gastpar u. E. Werde: Histamin in Speicheldrüsen, Tonsillen und Thymes und adaptative Histaminbildung in der Gl. submaxillaris. Naunyn-Schmiedebergs Arch. Pharmak. exp. Path. 259, 319 (1968c).

- M. Hutzes, E. MatekJa, and F. WhrLe: In preparation.

-, u. K. Pflugar: Stoffwechsel und physiologische Funktion von Histamin im Magen. Klin. Wschr. 46, 57 (1968d).

- - u. E. WERLE: In vitro-Hemmung der Histidindecarboxylasen durch antithyreoidale Substanzen. Biochem. Pharmacol. 17, 539 (1968e).

-, and E. WERLE: Inhibition of the salivary secretion by antihistaminic drugs and the question of a physiological rôle of histamine in the submaxillary and parotid glands, p. 362. Abstr. Intern. Congress of Pharmacology, Basel (1969a).

- Occurrence, cellular distribution and subcellular localization of histamine in man, animals and plants. Int. Encyclopedia of Pharmacology and Therapeutics. Oxford: Pergamon Press 1969 (in press).

MacIntosh, F.C., and W.D.M. PATON: The liberation of histamine by certain organic bases. J. Physiol. (Lond.) 109, 190 (1949).

MTNARD, D.: The presence and distribution of histamine in blood. Amer. J. Physiol. 132, 327 (1941).

Mota, I., W. T. Beraido, A. G. FerRI, and L. C. U. JunqueIRa: Intracellular distribution of histamine. Nature (Lond.) 174, 698 (1954).

- A. G. Frerr, and S. YoNeDA: The distribution of mast-cells in the digestive tract of laboratory animals: its bearings on the problem of the location of histamine in tissues. Quart. J. micr. Sci. 97, 251 (1956).

RIIEY, J. F.: The mast cells. Edinburgh-London: E. \&. S. Livingstone 1959.

-, and G. B. West: The presence of histamine in tissue mast cells. J. Physiol. (Lond.) 120, 528 (1953).

ScHAder, A.: The mast cell. In: Veröffentlichungen aus der morphologischen Pathologie, F. Buchner and W. Grese (Eds.). Stuttgart: G. Fischer 1964. 
Schadfr, A., u. E. WerLe: Zur histochemischen Darstellung des Histamins der Mastzellen. Z. ges. exp. Med. 131, 100 (1959).

SchaYER, R. W.: Formation and binding of histamine by free mast cells of rat peritoneal fluid. Amer. J. Physiol. 196, 189 (1956).

- Evidence that induced histamine is an intrinsic regulator of the microcirculatory system. Amer. J. Physiol. 202, 66 (1962).

SELYE, H.: The mast cells, p. 95. London: Butterworths 1965.

Shore, P. A., A. Burkhalter, and V.H.COHN, JR.: A method for the fluorometric assay of histamine in tissues. J. Pharmacol. exp. Ther. 127, 182 (1959).

SNyder, S. H., J. GLowInskI, and J. AxeLrod: The physiological disposition of $\mathrm{H}^{3}$-histamine in the rat brain. J. Pharmacol. exp. Ther. 153, 8 (1966).

Thunbera, R.: Localization of cells containing and forming histamine in the gastric mucosa of the rat. Exp. Cell Res. 47, 108 (1967).

Uvnäs, B., and I.L.THoN: A physico-chemical model of histamine release from. mast cells. In: Mechanisms of release of biogenic amines. Proc. International Wenner Gren Center Symposium Series, Vol. 5, p. 361. Oxford: Pergamon Press 1966.

Wetnshembatm, E. J., and D. J. Ferguson: Localization of carbon-14 from histamine in enterochromaffin cells. Gastroenterology 51, 1028 (1968).

Priv.-Doz. Dr. WrifRIEd LoRENz

Institut für Klinische Chemie

und Klinische Biochemie

8000 München 15, Nußbaumstr, 20 